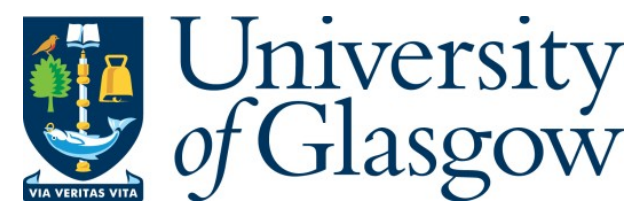

Gherghina, S. and Bankov, P. (2020) Who follows the referendum campaign? The effect of political interest and media use in Bulgaria. Problems of Post-Communism. (Early Online Publication)

(doi: $\underline{10.1080 / 10758216.2020 .1760722)}$

This is the Author Accepted Manuscript.

There may be differences between this version and the published version. You are advised to consult the publisher's version if you wish to cite from it.

https://eprints.gla.ac.uk/214719/

Deposited on: 29 April 2020

Enlighten - Research publications by members of the University of Glasgow http://eprints.gla.ac.uk 


\title{
Who Follows the Referendum Campaign? \\ The Effect of Political Interest and Media Use in Bulgaria
}

\author{
Sergiu Gherghina \\ Department of Politics \\ University of Glasgow \\ Petar Bankov \\ Department of Politics \\ University of Glasgow
}

\begin{abstract}
The content of referendum campaigns and their potential effect on voters has been broadly covered in the literature. However, there is little information about who follows the campaigns. We do not know the characteristics of the campaign audience and what drives voter's attention to it. To address this gap in the literature our article aims to identify what determines people who vote in referendums to pay attention to the political campaign. The analysis focuses on the 2016 referendum in Bulgaria and uses individual-level data from an original survey conducted in spring 2017. The findings indicate that high interest in politics and the use of traditional media increase the level of campaign following. The online news consumption and political participation have a lower positive effect.
\end{abstract}

Keywords: referendum campaign, political interest, media, political participation

\section{Introduction}

The large number of referendums organized across the world in the last four decades brought increased attention to the campaigns preceding them. As referendums have become a more regular component of decision-making, there has been a growing interest in the messages conveyed by the initiators, by the political actors involved in opposing or supporting the policy subjected to a referendum, and by the electorate at large. Much research has focused on the format and content of the referendum campaigns (O'Leary and Hesketh, 1988; Mendelsohn and Parkin, 200I; de Vreese, 2007) especially since the policies subjected to a popular vote gradually diversified from matters related to the political system or major internal policies towards addressing issues of external affairs, welfare policies or human rights. Earlier research analysed how issues are framed and presented to the public throughout the referendum campaigns (Domke, Shah and Wackman, 1998; de Vreese and Semetko, 2004; Wettstein, 2012). In this context, aside from media framing, referendum campaigns can further influence how people vote depending on whether voters follow the 
campaign or if they find the campaign informative (Farrell and Schmitt-Beck, 2003; Schuck and de Vreese, 2009; Gherghina and Silagadze, 2019).

While the literature covers the content of referendum campaigns and their potential effect on voters, there is little information about who follows the campaigns. We do not know the characteristics of the referendum campaign audience and what drives the voters' attention to the campaign. This is a major gap, as it prevents future studies on referendums to make informed hypotheses on the potential sources for referendum participation and referendum voting choice. Currently, media representation of referendums tends to frame them as tools that undermine the liberal democratic order across the world, given that referendums are often called or initiated by fringe and/or anti-political establishment actors'. Knowing who follows those campaigns and their reasons to do so, we will be able understand the role of referendums on democratic consolidation and regime legitimacy.

To address this gap in the literature our article aims to identify what determines people who vote in referendums to pay attention to the political campaign. The analysis focuses on the 2016 referendum in Bulgaria and uses individual-level data from an original survey conducted in spring 2017 on a convenience sample of 337 voters in that referendum. We focus exclusively on those who voted because they are the ones who also mainly engaged with the content of the referendum campaign. This case is appropriate to investigate the causes of campaign following among voters for several reasons. First, the referendum included voting on three different issues and thus the campaign had a rich content that could have appealed to large segments of society. Second, the campaign was initiated by a citizen's committee led by a television performer rather than any of the political parties (Stoychev, 2017). In doing so, the referendum is a case of bottom-up agenda setting, where personalities outside the political elite determine the topics of political debate. Such a bottom-up origin should naturally encourage mass interest, as it allegedly addresses a topic of public interest. Furthermore, the bottom-up origin of this referendum is representative of the growing plethora of grassroots initiatives in Central and Eastern Europe in recent years that saw the staging of referendums on same-sex marriage in Croatia (20I3) and Romania (2018), for example. Third, the country has very limited experience with referendums, a characteristic that prevents voter's fatigue in relation to campaigns

1 Recent examples of such referendums include the EU membership referendum in the UK, called following the increasing pressure of UKIP on the Conservative Party; the referendum on the EU-Ukraine free trade agreement in the Netherlands, called by an provocative blog; the migrant quota referendum in Hungary, called by the radical right government of Fidesz. 
about direct democracy. Four, the referendum faced almost universal blackout from major political actors and media. These circumstances enable us to assess the effects of campaign following and the voters' individual background in fairly isolated conditions without any theoretical or empirical concerns of the potential interference of media framing or party cues that usually affect such studies.

The central argument of this article is that people who have an interest in politics, use the channels of communication used by the initiator and who already participate in politics are more likely to follow the campaign. Voters with this profile are more disposed to actively seek information regarding a decision that could have important effects in their lives. In contemporary democracies, referendums are, together with elections, important modes of political participation through which citizens have a say in the democratic decision-making process. In spite of the differences between these two mechanisms, including some particular features of their campaigns (LeDuc, 2002), they serve similar purposes. Under these conditions, the drivers that impact citizen's motivation to follow the campaigns are likely to be similar. For these reasons, we test the explanatory power of several attitudinal and behavioural variables, derived from the fields of political participation and political communication. We formulate hypotheses and empirically test the explanatory potential of political interest, online news consumption, use of traditional media, political participation and perceived usefulness of referendums. We control for the effect of education and age. The analysis uses both bivariate and multivariate statistical analysis to explain the variation in following the referendum campaign.

The first section reviews the literature about campaign following and formulates four testable hypotheses. Next, we discuss the case selection, data, variable operationalization and methods used for analysis. The third section presents an overview of the Bulgarian referendum and introduces the main topics of the referendum campaign. The fourth section includes the results of hypothesis testing and interpretation of results. The conclusions explore the implications of this study and discuss avenues for further research.

\section{Referendum Campaigns and the Reasons to Follow Them}

A referendum campaign is polarising because the opposing camps use messages that try to push voters to make a choice. This choice is between Yes and No and, as such, the referendum campaigns have several particular features. One of those is the fact that voters are presented with a choice for an issue that is completely new to them. In some instances, 
they have clear cues from their preferred parties, but in others, they do not (LeDuc, 2002; Hobolt, 2007; Steenbergen, Edwards and de Vries, 2007). Usually, the cues are available when the referendums are on major issues, one of the recent examples in that direction being EU integration. In the absence of cues, the competence of voters in terms of their political knowledge and level of political interest, and their desire to acquire information play a relevant part (Lupia and Johnston, 200I; Mendelsohn and Parkin, 200I; Christin, Hug and Sciarini, 2002).

A second feature of the referendum campaign is that it often approaches a multifaceted issue (de Vreese, 2007). This allows the initiators to frame the issue as they please in order to attract public support. Earlier research showed that the initiator's popularity and the way they present the topic to the public can significantly increase the chances of a favourable vote in the referendum (Silagadze and Gherghina, 2018). Yet, the multifaceted nature of the question asked on the ballot is not only an advantage to the initiator, but to every other actor involved in the campaign. They can all frame the issue according to their interests and try to shape the popular vote.

A third feature of the referendum campaigns, derived from the first two, is its paramount importance for the final vote (LeDuc, 2002; de Vreese, 2007). The limited presence of partisanship or ideology in a referendum - because the topic transcends the political spectrum or parties are divided over it - makes the content of campaign crucial for the outcome of the referendum. Sometimes these campaigns can refer to other issues beyond the policy presented on the referendum ballot, e.g. the referendums on European integration in which the voters' attitudes towards the national government was the one shaping their decision in the referendum rather than the issue itself (Franklin, van der Eijk and Marsh, 1995; Taggart, 2006).

\section{Hypothesizing the Effects}

In general, the literature about referendum campaigns lacks a discussion regarding the reasons for which people follow the campaign. As a result, most of the logical mechanisms presented in this section are inspired by the literature dealing with election campaigns. The arguments do not travel easily across the two types of campaigns (election and referendum) since there are a few noticeable differences between them (LeDuc, 2002). Among the most important ones is the existence of a partisan vote in elections where the campaign is oriented towards competing values, ideas and ideologies. In referendums, there is only one 
policy to be decided upon, even when it may be a subject to multifaceted interpretations and framings, and very often that policy is not aligned along the usual lines of competition. For example, in some instances it may cut across the political spectrum, bringing into the same camp political parties of a different ideology. In other instances, the referendum topic, and implicitly campaign, may internally divide a political party (de Vreese and Semetko, 2004; de Vreese, 2007). For these reasons, only some elements of election campaigns can be paralleled to referendums.

Interest in politics is one such a factor, which is the strongest predictor of use of general campaign information in British elections (Norris and Curtice, 2008). People with limited interest in politics are, in general, difficult for campaigners to reach. The absence of interest means they do not pay attention to political advertisements, rallies, leaflets, canvassing and any other activities associated with a campaign. Televised debates are the element of political campaigns with the greatest potential to attract people with low interest in politics (Maier and Faas, 20II). This happens because the debate captures the essence of the campaign and allows voters with low interest in politics to get cues from a short performance. The results of debate watching in Germany indicate that people with low interest in politics follow these events to a considerably lower extent than those viewers who have an interest in politics (Maier and Faas, 20I I).

A second reason that could drive voters to follow a campaign is news consumption. This is a proxy for the high level of information acquired by voters. The latter receive information about the views and traits of mass collectives, which can affect political attitudes and positions (Anderson and Goodyear-Grant, 2010). Citizens who actively seek general information in the news are likely to continue this approach throughout the campaign and thus follow them. Empirical evidence shows that news consumers are more likely to watch events organized during campaigns (Kenski and Stroud, 2005; Kenski and Jamieson, 20I I). Earlier studies indicate that online publishing, social networks, and web searches have lowered the costs of producing, distributing, and discovering news articles (Flaxman, Goel and Rao, 2016). Overall, the use of online news is increasing, while news consumption from traditional media declines steadily (Norris and Curtice, 2008; Flaxman, Goel and Rao, 2016). Consequently, online news consumers, in particular, are more likely to engage in discussions about elections (Norris and Curtice, 2008).

This desire to engage in conversations about the topic of the campaign makes them more likely to follow it. Furthermore, online news consumption increases the exposure of 
voters to political messages. When elections are announced the news covers the main candidates and amplify their ads (Ridout and Smith, 2008), a process which may convince consumers to follow the campaign in order to better understand those messages. Information spreads fast in the online environment and those who read news online can easily follow developments in the campaign.

The appearance of political blogs could be considered a game-changer. Emerging at the beginning of the 2000 s, these were used for several years in election campaigns until social media proved a much more effective and efficient tool to bring a message across. Research on readers of political blogs indicates that people who have higher levels of political interest are more likely to read them (Eveland and Dylko, 2006). These individuals follow what happens in society in general and they care about political developments. As such, they are more interested in learning various points of view, others' opinions and even expressing their own opinions. Political campaigns provide extensive opportunities to observe various perspectives and to engage in discussions on particular topics. People who are politically interested usually have viewpoints about a range of issues in society. A referendum campaign provides people with the possibility to observe whether the approaches towards the matter subjected to a vote are in line with their own perceptions or expose them to new information.

The use of traditional media is the third potential trigger for campaign following. People who use media do not do this only for news or only online. As the previous paragraph shows, there is a different trend of online news consumption than the use of traditional media. For these reasons, we expect the general use of traditional media to be a different predictor for the likelihood to follow a referendum campaign. The general use of traditional media includes entertainment or TV shows (for visual media) and opinion articles or editorials (print media), which can include important references to the referendum campaign. There are further reasons for which online news consumption and the use of traditional media are different. As earlier studies show, search for news in online environments is mainly pursued by individuals who are disenchanted with traditional media, which they do not trust, and turned to online sources of information (Tsfati and Cappella, 2003; Johnson and Kaye, 2004; Jones, 2004).

Traditional media can provide access to information for those segments of society without access to the internet. In the particular case studied in this article, statistics show that the percentage of internet users around the 2016 referendum was below $60 \%$, which 
means that a large share of voters was not exposed to online media. We expect the use of traditional media to have a positive impact on the propensity to follow the campaign. Traditional media channels were used extensively by political actors to promote their messages outside the campaign. The frequent use of traditional media increases the exposure to messages and could draw the attention of voters towards the specific campaign. One empirical detail makes the media use of particular relevance for the case investigated in this article. The referendum had been initiated by a person working in television, who started circulating information about the referendum in the traditional media before the campaign began. Being directly exposed to these contents, Bulgarian citizens who use traditional media could be more prone to follow the campaign.

Finally, citizens who are politically active are likely to follow the referendum campaign. The logic behind this argument is that individuals who already engage in one mode of political participation, such as voting, protesting, signing a petition, or boycotting, are usually more inclined to engage in other modes as well. The involvement is often preceded by information seeking, which can take place during campaigns. Modes of political participation have gradually developed over the last decades and today citizens have a plethora of opportunities to participate, both online and offline (Gibson and Cantijoch, 2013; van Deth, 2014; Theocharis and van Deth, 2017). Earlier research illustrates that, in spite of this diversity of modes of participation, there are close ties between them. The same causes explain the involvement in both offline and online participation, while findings indicate that roughly the same citizens participate in various modes, with online behaviour shaping the offline behaviour (Saglie and Vabo, 2009; Anduiza, Gallego and Cantijoch, 2010; Gibson and Cantijoch, 2013).

Following these arguments in the literature, we expect that four factors are likely to increase the level of following the referendum campaign: political interest $(\mathrm{HI})$, online news consumption $(\mathrm{H} 2)$, use of traditional media $(\mathrm{H} 3)$ and involvement in political participation $(\mathrm{H} 4)$. In addition to these four main effects, the analysis will also control for three determinants: perceived usefulness of referendums, education and age. The perceived usefulness of referendums is expected to have a positive effect on the likelihood of an individual to follow the campaign. Citizens are usually willing to get informed and eventually participate in a form that has meaning to them. Earlier research found also that education and age correlate positively with watching television debates between the main candidates 
(Kenski and Stroud, 2005; Norris and Curtice, 2008) and with other forms of political engagement (Brady, Verba and Schlozman, 1995; van Deth, Montero and Westholm, 2007). ${ }^{2}$

\section{Research Design}

To test these hypotheses, we use individual data from an original online survey conducted in March-April 2017 among the voters of the 2016 referendum in Bulgaria. Since we focus on voters in the referendum and the country does not collect socio-demographic information about who voted in that referendum, there is no possibility for a representative probability sample. For these reasons, we use a convenience sample that includes 337 complete answers to the questionnaire. The survey was distributed online through Facebook groups and discussion forums. The respondents could skip any question, but not many did so. The age of respondents is between 18 and 74 years old with almost half of the sample being 25 years old or under. This age bias, combined with a self-selection bias due, make us cautious about the interpretation of the result. There is a lot of variation in terms of other sociodemographic characteristics (e.g. gender, education) within the sample. The conclusions of our analysis are confined to the sample of voters included in this survey and not generalizable to the broader population in Bulgaria. Still, the discussion also looks into the survey results in the context of general media use in Bulgaria, thus aligning our conclusions with the country-specific background.

The 2016 referendum in Bulgaria is an appropriate setting to study our dependent variable (i.e. following the campaign) for a few reasons. First, the referendum posed three questions that address significant aspects of the Bulgarian political system ${ }^{3}$. In doing so the referendum enables wider voting mobilization that engages different parts of society. This is particularly evident in the referendum turnout that was the highest among the three referendums the country held since the fall of the communist regime in 1989. While in 2013

\footnotetext{
${ }^{2}$ The analysis tested for a series of other control variables such as party for which the respondents voted in the most election before the referendum, ideological self-placement, trust in media (since the initiator of the Bulgarian referendum is a media person), importance of the topic, opinion before the campaign and gender.

3 The referendum questions in their original wording were the following: I) Подкрепяте ли народните представители да се избират с мажоритарна избирателна система с абсолютно мнозинство в два тура? (Do you support members of parliament to be elected by a majoritarian electoral system with absolute majority in two rounds?); 2) Подкрепяте ли въвеждането на задължително гласуване на изборите и референдумите? (Do уоu support the introduction of compulsory voting on elections and referendums?); 3 ) Подкрепяте ли годишната държавна субсидия, отпускана за финансиране на политическите партии и коалициите, да бъде един лев за един получен действителен глас на последните парламентарни избори? (Do you support that the yearly state subsidy provided to political parties and coalitions to be one Bulgarian Lev for one received valid vote on the last parliamentary elections?) (Central Electoral Commission, 2019b)
} 
only $20.2 \%$ voted on the referendum about the building of a new nuclear power plant (Central Electoral Commission, 2019c) and in 2015 39.7\% participated in the constitutional reform referendum, initiated by the Bulgarian president in 2015 (Central Electoral Commission, 2019a), 50.8\% voted in the 2016 referendum (Central Electoral Commission, 2019b). While this increased activity can be partially explained by the fact that the referendum was held on the same day as the first round of presidential elections, nevertheless it shows a remarkable mobilization, given that people had the option to refuse a referendum ballot. Second, in contrast to the previous referendums, this was organised by a civic committee, unaffiliated with the existing political parties in Bulgaria. This referendum remained to a large extent exempt from the noticeably partisan divisions that marked the previous referendums in the country. Such a grassroots mobilisation initiative is more than relevant given that the referendum result was to overwhelming support the proposed constitutional changes, even though the referendum barely missed the turnout threshold that would make the outcome legally binding. Given that the referendum faced noticeable scepticism by the national media and political elite, as it will be discussed in the following section, it is also a suitable case for understanding the effects of voters' media use and political interest independent of party cues or media framing. Third, Bulgaria has limited experience with referendums. Since the re-establishment of the Bulgarian state in 1878, the country held only six popular votes on policies out of which the last three have taken place since 2013. In the context of our research, this case serves as a tabula rasa for the sources of following the referendum campaign given the overall absence of voter fatigue on direct democracy. On the contrary, as it will be shown later in our article, recent years show rising social demand for political engagement In Bulgaria.

\section{Variable operationalization and methods}

The dependent variable of this study is the degree of following the referendum campaign, measured through the question "How much did you follow the referendum campaign?". Possible answers were recorded on a four-point ordinal scale ranging from not at all (coded I) to very much (coded 4). The interest in politics $(\mathrm{HI})$ is measured on a similar four-point ordinal scale. Online news consumption $(\mathrm{H} 2)$ "How often do you use online news portals?" and the available answers range from never (I) to daily or almost daily (5). The media exposure $(\mathrm{H} 3)$ is an additive index that includes TV and newspaper. The question aiming to capture consumption of traditional news media is "How often do you watch TV / read 
newspapers?" and the available answers range from never (I) to daily or almost daily (5). All of these questions on media use refer to media use by voters, captured in the survey. In this respect, our analysis assumes that media use does not differ significantly during and outside the referendum campaign.

The political participation $(\mathrm{H} 4)$ is an additive index computed out of five modes of political participation: vote in elections, vote in a referendum, protest or demonstration, petition signing and products boycott. The respondents were asked which of these they have done in the last five years and each of the modes of participation is a dummy $(I=$ presence of the outcome). The index of political participation takes values between 0 when an individual was completely passive to 5 for individuals who used all five modes of participation. The perceived usefulness of referendums is operationalized through the answer provided to the question about how useful referendums are for the Bulgarian political system. Available answers range from not at all (coded I) to very useful (coded 4). Education is measured on a five-point ordinal scale ranging from primary school to postgraduate degree. Age is a straightforward measure in years at the time of the survey.

The analysis uses a two-step approach. We start with bivariate statistical analysis in the form of non-parametric correlations due to the ordinal measurement for most variables. The purpose of correlations is to see how campaign following co-varies in relationship to each of the independent and control variables. The second step consists of ordinal logistic regression with two distinct models - one with and one without controls. We report the statistical significance more to show the robustness of effects rather than to make generalisable interpretations to a broader population.

\section{Overview of the 2016 Bulgarian referendum}

The 2016 referendum is commonly known as "Slavi's referendum", named after Stanislav "Slavi" Trifonov, the main person behind it. A popular show host, musician, and producer, Trifonov has a successful career in the past three decades. Pivotal for this were the television shows with his involvement, especially the most recent one called Slavi's Show that maintains a significant public following for their sharp political commentary and anti-systemic and nationalist discourse, among others (Kourtova, 2012). Trifonov's regular clashes with the government, resulting in several cancellations of his shows throughout the years, further solidified his image as an influential public figure. Yet, despite his anti-systemic talk and personal popularity, his political involvement was rather unsuccessful, including a failed 
attempt to form a political party during the 1990s, and the endorsement of unsuccessful parliamentary and presidential candidates in the past decade. In this context, Trifonov's call for a referendum in July 2015 reflected his continuous attempts to influence Bulgarian politics.

This attempt had a fruitful social and political ground. First, there was a clear rise of social tensions in Bulgaria in the years preceding the referendum. In February and June 20I3 the country experienced two waves of mass protest that resulted in the resignations of both centre-right and centre-left governments and the staging of two early elections in 2013 and 2014 with the lowest electoral turnouts to this date (Kostadinova and Popova, 20I4, 20I5). A growing public disillusionment with Bulgarian politics was clearly noticeable: according to Eurostat while in May 2012 trust in the national government and parliament was at, respectively, $27 \%$ and $17 \%$, by November 2014 they dropped to $19 \%$ and I4\% and could not recover by the time of the referendum remaining at 24\% and I2\% (European Commission, 2012, 2014, 2016). Similarly, satisfaction with democracy was still weak: while between May 2012 and 2016 there has been about $10 \%$ increase in the number of Bulgarians being very or fairly satisfied with the way democracy in the country works (from $20 \%$ in 2012 to $30 \%$ in 2016), the overall level of satisfaction is still far below than the EU average in May 2016 of $51 \%$. This is a particularly fruitful ground for Trifonov to exploit, given his previous success in addressing public disillusionment. For example, he was one of the main popular figures behind the protest campaign that brought down the left-wing government of the Bulgarian Socialist Party during the Bulgarian economic crisis of 1996-1997.

Second, the majority of the Bulgarian political elite seemed reluctant in addressing this mounting discontent. The most concrete and by far substantial attempt to engage citizens in national politics and improve accountability in the aftermath of the 2013 protest wave came from the Bulgarian president, Rosen Plevneliev. In January 2014 he initiated a referendum, proposing three changes in the electoral system: a change from a proportional representation system to a mixed-member one; the introduction of compulsory voting; the introduction of online voting. The initiative faced significant opposition by the Bulgarian parliament (Stoyanov, 2015), ending with the rejection of the first two questions and organizing a referendum on the third one. It was this parliamentary decision to reject the more fundamental proposals to change the electoral code that prompted Trifonov to call for a further referendum on these matters (Slavi's Show, 20I5b). While Plevenliev's initiative received resounding public support $(72.8 \%$ voted in favour of the introduction of online 
voting), it failed to have the same voting turnout as the latest parliamentary election (in this case $55.1 \%$, which prevented making the outcome of the referendum legally binding. This suggests that there was a public demand to reform the Bulgarian political system that could not be captured by the contemporary Bulgarian party system.

A day after the 2015 referendum, Trifonov declared that "the only way apart from a civic revolution is us, the Bulgarian citizens, [...] to change this vicious, visibly unworkable, and degrading system" (Slavi's Show, 2015a). To do so, he formed and headed a civic committee with the aim of gathering the legally required number of signatures $(400,000)$ to call for a referendum on the introduction of six major changes of the Bulgarian political system: the change of the PR electoral system to a two-round majoritarian one; the reduction of the parliament size from 240 to $120 \mathrm{MPs}$; the introduction of compulsory voting; the introduction of online voting; the reduction of state funding regulations for parties to I Bulgarian Lev per vote; the direct election of head police commissioners of regional and local police stations (Slavi's Show, 2015c). The initiative gained significant traction during the winter of 2015 , succeeding in gathering the required signatures by its February 2016 deadline (Dnevnik.bg, 20I5).

Despite its popularity, Trifonov's initiative faced significant resistance from the Bulgarian president and parliament. In May 2016, the country president brought a case against the referendum to the Constitutional Court arguing against the constitutionality of the proposals on reducing the parliament size, introducing online voting and directly electing police commissioners (Constitutional Court of the Republic of Bulgaria, 2016). The ensuing legal battle ended in July 2016 with a court decision to remove these three questions from the ballot (Constitutional Court of the Republic of Bulgaria, 2016). Moreover, the Bulgarian parliament changed the electoral code in April 2016, preventing the referendum being held on the same day as the upcoming presidential elections in the autumn of 2016 , and thus potentially reducing the eventual electoral turnout. Yet, the legal issues involving the Constitutional Court prevented the parliament from staging the referendum in August, as originally planned, allowing the president to schedule it for 6 November 2016, the day of the presidential elections (Mediapool.bg, 2016).

The referendum campaign, however, lacked intensity. This was mainly due to the almost complete absence of major political parties or organisations engaging with either side of the referendum questions. This was a major difference from Pleveneliev's referendum, which was supported by the majority of liberal right parties in Bulgaria. This time around, 
however, these parties expressed significant concerns with the wording of the questions, leaving no major party even filing a referendum committee aside from the parliamentaryrepresented Alternative for Bulgarian Revival (Central Electoral Commission, 2016). Furthermore, the state-funded media coverage of campaign messages were provided to minor regional and local media rather than major national outlets (Dnevnik.bg, 2016a) further limiting the avenues for mobilization. The general discourse of the established traditional and online Bulgarian media was highly critical of the referendum. Whereas government-friendly media branded it as a wasteful affair that fuels Trifonov's political ambitions (Simov, 2016), opposition outlets rejected the initiative as populist and even as beneficial for the major political parties, given the proposal on introducing a majoritarian electoral system and substantially reducing party funding (Konstantinov, 2016). In such circumstances, the referendum campaign was largely televised, as Trifonov relied mainly on his evening show to mobilise support. The final effort in this respect was a major public concert by Trifonov's music band, Cuckoo Band, a couple of days before the referendum day that blocked one of the main streets in Sofia.

In spite of all this, there was support for the three referendum questions. $71.9 \%$ of the voters supported the switch to a majoritarian electoral system, whereas $61.9 \%$ and $72.2 \%$ were in favour of, respectively, the introduction of compulsory voting and reduction of state funding for political parties. Yet, the referendum failed in its main goal - to change the Bulgarian political system. Despite the overwhelming support and reasonably high participation (turnout was 49.5\%), the result failed to pass the turnout threshold to make it legally binding by about 13,000 votes (Dnevnik.bg, 2016b). Yet, it served as further confirmation for the lasting public discontent with Bulgarian politics. As it will be seen in the subsequent analysis, this discontent had different manifestations, reflected in the extent the voters' political interest and engagement, as well as their particular form of news consumption (online or traditional), drove them to follow the campaign.

\section{Political Interest and News Consumption}

As a first step in presenting the results, we map out the distribution of respondents on the dependent variable. Only a very small share of those who answered the survey did not follow the campaign at all (2.4\%) and roughly one in six respondents followed it only a little (16.7\%). One in five respondents followed the campaign very much $(20.9 \%)$, while a great 
share of the respondents followed the campaign much $(60 \%)$. This is the variation that we try to explain with the statistical analysis below.

Table I includes the correlation between campaign following and each of the other variables explored in the theoretical section. The values of the coefficients indicate empirical support for all four hypothesized relationships. Those voters with a higher interest in politics, more news consumption, higher use of traditional media and who were already engaged in political participation follow the referendum campaign more than others. The strongest correlation is with interest in politics, while the weakest is with previous political participation. All correlation coefficients are statistically significant, with political participation being at a lower level of 0.05 . In the context of the referendum, this is to be expected given the lasting and increasing public discontent with Bulgarian politics in recent years which seems to have engaged people with limited prior political activities.

Among the controls, age is the only variable that is statistically significant, as with the larger coefficient. The direction of the correlation indicates that - within our sample of respondents - younger people followed the referendum campaign in Bulgaria more than older respondents. The correlations indicate also that respondents who find referendums useful for Bulgarian politics and those who are less educated are slightly more inclined to follow the campaign compared to the other respondents. Both factors are somewhat in line with existing exit poll data that highlights that people with high school and university degrees participated mainly in the referendum (respectively $42.1 \%$ and $48.9 \%$ ), whereas people with primary education were in minority (9\%) (Gallup International, 2016).

\section{Table I: The Correlations between Campaign Following and other Variables}

\begin{tabular}{lcc}
\hline & $\begin{array}{c}\text { Correlation } \\
\text { coefficient }\end{array}$ & $\mathbf{N}$ \\
\cline { 2 - 3 } Interest in politics & $0.32^{* *}$ & 330 \\
Online news consumption & $0.25^{* *}$ & 307 \\
Use of traditional media & $0.27^{* *}$ & 307 \\
Political participation & $0.11^{*}$ & 330 \\
\hline Usefulness of referendums & 0.10 & 330 \\
Education & -0.06 & 300 \\
Age & $-0.14^{*}$ & 269 \\
\hline
\end{tabular}

Note: The reported coefficients are nonparametric. $* * \mathrm{p}<0.0 \mathrm{I} ;{ }^{*} \mathrm{p}<0.05$.

The regression analysis in Table 2 confirms to some extent the observations from the bivariate correlations. Model I includes only the main effects and has a small value of the pseudo $\mathrm{R}^{2}$, which shows a relatively poor model fit for the set of observations. The odds- 
rations indicate empirical support for the first three hypotheses. The respondents who have a high interest in politics are almost twice more likely to follow the campaign more when compared to those without political interest. This suggests that despite the significant disadvantages that the referendum campaign faced in terms of media exposure and engagement of political organisations, it succeeded in attracting people that were interested in the political developments in Bulgaria. Given that the campaign was largely a product of Slavi's Show, it seems that this is also a reflection of his audience, given the highly political character of his show.

Online news consumption has a positive effect on campaign following, statistically significant at the $0.0 \mathrm{I}$ level. Respondents who read daily or almost daily news online are I.35 times more likely to follow the campaign when compared to those who do not read the news at all. This is a rather unusual observation given the context of the referendum. As it will be discussed in more detail in the following paragraphs, the majority of voters on the referendum come from places with limited online access. Given the lack of significant media coverage on the referendum beyond Slavi's Show and the regional and local outlets, this finding seems to provide an important insight into the dynamics among the opponents of the referendum proposals. Particularly telling in this respect was the engagement of the Bulgarian blogosphere with the referendum. While politically active Bulgarian bloggers expressed their views on the referendum and offered a rich discussion of its questions, a significant majority remained highly critical of it (Bozhanov, 2016; Encheva, 2016). In this context, the final days of the campaign even saw calls from Bulgarian bloggers and social media influencers to abstain from the referendum in order to prevent it from having a legally binding result (Bedrov, 2016; Minchev, 2016). In this context, given that our survey reflects the voter's campaign following, it seems that these calls were not particularly convincing.

The use of traditional media has also a positive effect, but its size is smaller than online media following (I.I3) and statistical significance at the 0.05 level. One potential explanation for this effect is the role played by Slavi's Show in mobilisation. This data suggests that the show seemed to have succeeded in persuading parts of the Bulgarian society to follow the referendum topics and eventually participate. However, its reach remains rather limited compared to the extensive media coverage of the presidential elections, for example. This is particularly evident in the failure of Slavi's show to mobilise the same level of voters as the presidential elections did: although both votes where held on the same day, there is almost $8 \%$ difference between their turnouts (Central Electoral 
Commission, 2019b). More importantly, given that state-funded media coverage was provided mainly to local and regional outlets, as mentioned in the previous section, it seems that the less influential role of traditional media than online one in following the campaign stems from this specific institutional decision which hindered a wider distribution of referendum-related news.

The only hypothesis that does not find empirical support is political participation, the results showing that this variable has a weak negative effect on campaign following. One possible explanation for this may be the anti-systemic nature of the referendum. Overall, the campaign succeeded in mobilizing those social groups in Bulgaria that were interested in politics but had remained politically disengaged in the past. This is important, as it highlights a significant protest potential in the Bulgarian society that was, potentially, not reached by the social and anti-corruption protests of 2013. Furthermore, the slightly negative effect of this factor can be explained with the overwhelming opposition by a significant portion of the politically active Bulgarian citizens, as evident in the positions of the Bulgarian blogosphere and social media, discussed above.

\section{Table 2: The Ordered Logistic Regression for Campaign Following}

\begin{tabular}{lcc}
\hline & Model I & Model 2 \\
\cline { 2 - 3 } Interest in politics & $\mathrm{I} .94^{* *}(0.3 \mathrm{I})$ & $2.12^{* *}(0.37)$ \\
Online news consumption & $\mathrm{I} .35^{* *}(0.15)$ & $\mathrm{I} .2 \mathrm{I}(0.15)$ \\
Use of traditional media & $\mathrm{I} .13^{*}(0.06)$ & $\mathrm{I} .17^{* *}(0.07)$ \\
Political participation & $0.95(0.1 \mathrm{I})$ & $\mathrm{I} .07(0.13)$ \\
\hline Usefulness of referendums & & $\mathrm{I} .29(0.18)$ \\
Education & & $0.82(0.20)$ \\
Age & 305 & $0.97^{*}(0.0 \mathrm{I})$ \\
\hline $\mathrm{N}$ & $-28 \mathrm{I} .28$ & 266 \\
\hline Log likelihood & 0.08 & -248.60 \\
\hline Pseudo $\mathrm{R}^{2}$ & & $0.1 \mathrm{I}$ \\
\hline Note: The reported coefficients & are odds-ratios & (standard errors in \\
parentheses). ${ }^{* *} \mathrm{p}<0.0 \mathrm{I} ;{ }^{*} \mathrm{p}<0.05$. & &
\end{tabular}

In Model 2, when controls are introduced, the pseudo $\mathrm{R}^{2}$ reported here indicates that this model better fits the outcome data than the model without controls. Important for the substance of this analysis, the effect of political participation changes and goes in the hypothesised direction. However, it is quite weak and not statistically significant. While this confirms that the campaign managed to reach out and mobilise these social groups, interested in politics, but politically inactive, the extent it succeeded in doing so should not be overestimated. All other main effects tell a similar story to Model I, with the partial 
exception of online news consumption which loses significance. In the context of the discussion on the influence of the Bulgarian blogosphere above, it seems that its calls to abstain on the referendum had some effect on the referendum participation. Again, as with the mobilisation reach of the campaign, however, their influence should not be overestimated, thus, highlighting the rather limited social influence of online media on Bulgarian society.

Among the controls, age is the only statistically significant variable with younger respondents being on average more likely to follow the campaign. This result has to be confined to our convenience sample that includes many young respondents. Nevertheless, the observed effect indicates that campaign following does not match the general conclusions regarding youth apathy. Young people are more inclined to follow what happens before a vote especially when they are committed to participation (all respondents in our survey were voters in the referendum).

Respondents who consider referendums as useful for Bulgarian politics are 1.29 times more likely to follow the campaign. While the role of age and education has been discussed above, it is important to say a few words about the influence of this perception regarding the usefulness of referendums. It highlights the potentially rising importance of referendums in the Bulgarian context. Particularly, the lack of substantial institutional reaction to the increasing public discontent with Bulgarian politics since 2013 seems to aid participation in referendums. For example, while the Bulgarian parliament changed the electoral code and introduced the opportunity for preferential voting, it also set a very high threshold of $7 \%$ for it, deeming this innovation rather ineffective. Another institutional innovation by the Bulgarian parliament, the introduction of a permanent committee for relations with civil society and handling civic complaints in 2013 , was also ineffective as it was boycotted by opposition organisations (Dnevnik.bg, 20/3). In such context, it seems that the referendum campaign succeeded in mobilising even people that do not necessarily view referendums as useful Bulgarian politics, as it represents one of the few options for direct civic engagement with government institutions in demanding reform of the Bulgarian political system.

Figure I graphically depicts the two strongest effects on the likelihood to follow the referendum campaign in Bulgaria. The vertical axis is the extent to which a respondent follows the campaign. The range of numbers on the horizontal axes differs due to the variable coding (see the research design). Figure la illustrates that respondents who have 
higher interest in politics are more likely to follow the referendum campaign. The strong positive effect is reflected in the increase of following the campaign along the various degrees of political interest. Those who are very interested in politics, situated at 4 on the horizontal axis, are two times more likely to follow the campaign when compared to those with no interest in politics, positioned at $\mathrm{I}$ on the same axis. Figure $\mathrm{Ib}$ indicates that a regular use of traditional media increases the likelihood to follow the campaign for referendums. Those respondents who read TV and read newspapers daily or almost daily (point 10 on the horizontal axis) follow the campaign to a larger extent than those who never get in touch with traditional media. The positive effect can be observed across various degrees of media use although it is less steep than political interest.

Figure I: The Effect of Interest in Politics (a) and Use of Media (b) on Campaign Following

a

While the relevance of both variables has been discussed above, it is worth highlighting why the use of traditional media has an important effect on referendum campaign following in Bulgaria. The main explanation for this is the dominance of Slavi's Show as the main outlet for mobilising support. According to exit poll data on the referendum participation, voters are predominantly from outside Sofia, particularly living in either regional centres or rural areas, which coincides with the main limits of the geographical spread of the internet in Bulgaria (Gallup International, 2016).

In particular, it seems that the majority of referendum voters come from places that have more limited access to online news outlets and seem to rely on traditional media (IHS Markit and Point Topic, 2017, Pp. 59-64). This result matches earlier findings from election campaigns according to which citizens are exposed to a variety of elements from traditional media, not only those related to news. For example, a study on Italy reveals how a tabloid 
newspaper covers the political and personality topics associated with a particular leader (Ciaglia and Mazzoni, 2015). The political content of a campaign moves beyond news and is reflected in entertainment, coverage of mundane activities or editorial sections of visual and print media. These sections are appealing also to people with low political interest, who do not actively pursue knowledge about the referendum. With high exposure to political information, these individuals become more likely to follow the debates.

Furthermore, the literature on referendums shows that the content of campaigns is often informative, characterized by strong and mobilising messages (Mendelsohn and Parkin, 200I; Schuck and de Vreese, 2009; Gherghina and Silagadze, 2019). These features become even more important when traditional media is the main source of information. Empirical evidence shows that traditional media is usually consumed by older Bulgarians (Nielsen Admosphere Bulgaria, 2016). At the same time, older people appear to have voted more in the 2016 referendum according to poll data (Gallup International, 2016). As a result, traditional media remains a consistently relevant factor explaining the variation in following the referendum campaign. In contrast, the use of online media rather motivated people to abstain from participating in the referendum, thus providing little incentive for people that consume it to continue to follow the campaign.

\section{Conclusion}

Referendums have gained momentum in recent decades and an increasing number of countries uses them for decision-making in politics. As such, it has become relevant to understand whether campaigns can make a difference. Part of the equation is who follows these campaigns. This article aimed to explain why voters in a referendum follow the campaign by using a single case study approach with a focus on the 2016 referendum in Bulgaria. Our original survey data reveals that Bulgarian voters followed the campaign due to their high interest in politics and their use of traditional media. As such, general attention paid to politics and to the initiator - in this case, the initiator of the referendum is a prominent figure from television - determined respondents to follow also what happens with a particular initiative. Online news consumption and prior political participation also increase the likelihood of following the campaign but have limited explanatory power. In the context of the anti-system character of this referendum, one could argue that some segments of society that feel alienated from Bulgarian politics, and thus with limited news 
consumption and political participation, were attracted by its idea and followed the campaign.

The implications of our analysis reach beyond the case study and convenience sample used here. This is the first study aiming to understand what drives citizens to follow a referendum campaign. Its findings can contribute to the advance of knowledge in the field of referendum campaigns and citizens' reactions to them. This article proposes a theoretical framework inspired by the literature on elections, which is not context specific and can be replicated in other political settings. The Bulgarian referendum can be seen mainly as an exploratory in the direction of identifying explanations. While the analysis has several limitations due to the convenience sample used, it reveals a number of important results. The combination of political attitudes and socio-demographics reflects the sophisticated processes behind the decision to follow a referendum campaign, very similar to those from electoral campaigns. The contribution made by this study to the field of referendums is the theoretical modelling of a behaviour that is often under-explored.

At an empirical level, our study indicates that citizens respond to similar stimuli about referendum campaigns as they do in elections. These findings are relevant especially for the debate regarding the specificity of the referendum and election campaigns. In spite of their differences in terms of content and outcome, these two types of campaigns attract voters with a similar profile: interested in politics and following the developments in society. Another important finding is the existence of separate effects for online news and traditional media. This is relevant especially in the context of increased use of social media and declining use of traditional media in contemporary societies. Earlier works merged the two and our findings reveal that this may no longer be a suitable approach to understand the dynamic of referendum campaigns. While the experience of the 2016 referendum in Bulgaria demonstrated the lasting influence of traditional media on voter mobilisation on referendums, its more limited impact compared to online media suggests that traditional media does not guarantee optimal voter mobilisation. Finally, the referendum campaign in Bulgaria was followed to a fairly equal extent by more and less educated citizens, a finding that contradicts several recent claims according to which less educated people are more oriented towards direct democracy.

Far from identifying all the key variables with explanatory power, this study opens the door to comparative studies on this understudied topic in new and established democracies. More sophisticated theoretical frameworks could include variables related to 
issue saliency, i.e. hot important the topic subjected to a referendum is for voters, specific attitudes towards political institutions or issues related to the content of referendum campaigns. More complex information could help grasp a more thorough understanding of the meaning of campaign following and semi-structured interviews or focus groups may be appropriate methods to collect such data. Furthermore, the higher importance of traditional media could have been a contextual finding given the nature of the initiator and further research could test the validity of this observation in different settings. 


\section{List of references:}

Anderson, C. and Goodyear-Grant, E. (2010) 'Why are highly informed citizens sceptical of referenda?', Electoral Studies, 29(2), pp. 227-238.

Anduiza, E., Gallego, A. and Cantijoch, M. (2010) 'Online Political Participation in Spain: The Impact of Traditional and Internet Resources', Journal of Information Technology \& Politics, 7(4), pp. 356-368.

Bedrov, I. (2016) Moite tri prichini izobshto da ne glasuvam na referenduma [My three reasons not to vote on the referendum at all].

Bozhanov, B. (2016) Nakratko za referenduma na Slavi [Briefly about Slavi's referendum].

Brady, H., Verba, S. and Schlozman, K. L. (1995) 'Beyond SES: A Resource Model of Political Participation', American Political Science Review, 89(2), pp. 27I-294.

Central Electoral Commission (2016) Publichen elektronen registar na initsiativni komiteti, partii i koalitsii za uchastie $v$ informatsionno-razyasnitelnata kampania $v$ natsionalniya referendum na 6 noemvri $2016 \mathrm{~g}$. [Public online registry of the civic committees, parties, and electoral allian.

Central Electoral Commission (2019a) Aktivnost na glasuvane - Mestni ibori i nationalen referendum 2015 [Voter turnout - Local elections and national referendum 2015].

Central Electoral Commission (2019b) Aktivnost na glasuvane - Prezident $i$ vitseprezident na Republikata i Natsionalen referendum 2016 [Voter turnout - President and Vice President and National referendum 2016].

Central Electoral Commission (2019c) Aktivnost na glasuvane - Referendum 2013 [Voter turnout - Referendum 2013].

Christin, T., Hug, S. and Sciarini, P. (2002) 'Interests and information in referendum voting: An analysis of Swiss voters', European Journal of Political Research, 4I (6), Pp. 759-776.

Ciaglia, A. and Mazzoni, M. (2015) 'The politicization of entertainment media: A study of the Italian tabloid Chi during the 2013 electoral campaign', Journalism, 16(6), pp. 8I2-829.

Constitutional Court of the Republic of Bulgaria (2016) Decision № 9 on case 8 / 2016.

van Deth, J. W. (20I4) 'A conceptual map of political participation', Acta Politica, 49(3), pp. 349-367.

van Deth, J. W., Montero, J. R. and Westholm, A. (eds) (2007) Citizenship and Involvement in European Democracies: A Comparative Analysis. New York: Routledge.

Dnevnik.bg (2013) Nad sto predstaviteli na grazhdanski organizatsii obsazhdaha promeni $v$ izborniya kodeks [Over 100 representatives from civic organisations discussed changes in the electoral code].

Dnevnik.bg (2015) 'Shouto na Slavi' e sabralo 600 hil. podpisa za provezhdane na referendum ["Slavi's Show" gathered 600,000 signatures for a referendum].

Dnevnik.bg (2016a) Darzhavni pari za agitatsia za refrenduma otivat $v$ medii s malka auditoria [State funds for the referendum campaign go to media with small audience].

Dnevnik.bg (2016b) Okolo 13 hil. glasa ne dostigat, za da bade referendumat zadalzhitelen [About 13,000 votes lacked to make the referendum legally binding].

Domke, D., Shah, D. V. and Wackman, D. B. (1998) '\&quot;Moral Referendums\&quot;: Values, News Media, and the Process of Candidate Choice', Political Communication, I5(3), pp. 30I-32I.

Encheva, S. (2016) Referendumat na Slavi: 6+l 'ne' i I 'da' [Slavi's referendum: 6+l times 'no' and I 'yes'].

European Commission (2012) 'Eurobarometer 77.3, May 2012'.

European Commission (2014) 'Eurobarometer 82.3, November 2014'.

European Commission (2016) 'Eurobarometer 85.2, May 2016'.

Eveland, W. P. J. and Dylko, I. (2006) 'Reading Political Blogs During the 2004 Election Campaign: Correlates and Political Consequences', in Tremayne, M. (ed.) Blogging, 
Citizenship, and the Future of Media. London: Routledge, pp. 105-126.

Farrell, D. M. and Schmitt-Beck, R. (eds) (2003) Do political campaigns matter? Campaign effects in elections and referendums. London: Routledge.

Flaxman, S., Goel, S. and Rao, J. M. (2016) 'Filter Bubbles, Echo Chambers, and Online News Consumption', Public Opinion Quarterly, 80(SI), pp. 298-320.

Franklin, M. N., van der Eijk, C. and Marsh, M. (1995) 'Referendum outcomes and trust in government: Public support for Europe in the wake of Maastricht', West European Politics, 18(3), pp. 101-II7.

Gallup International (2016) Podrobni demografski profili i nyakoi nablyudenia [Detailed demographic profile and some observations].

Gherghina, S. and Silagadze, N. (2019) 'And yet it matters: referendum campaigns and vote decision in Eastern Europe', Contemporary Politics, 25(I), PP. 29-46.

Gibson, R. and Cantijoch, M. (2013) 'Conceptualizing and Measuring Participation in the Age of the Internet: Is Online Political Engagement Really Different to Offline?', Journal of Politics, 75(3), pp. 70I-7I6.

Hobolt, S. B. (2007) 'Taking Cues on Europe? Voter Competence and Party Endorsements in Referendums on European Integration', European Journal of Political Research, 46(2), PP. I5I-I82.

IHS Markit and Point Topic (2017) Broadband Coverage in Europe 2016. Mapping progress towards the coverage objectives of the Digital Agenda.

Johnson, T. J. and Kaye, B. K. (2004) 'Wag the Blog: How Reliance on Traditional Media and the Internet Influence Credibility Perceptions of Weblogs Among Blog Users', Journalism \& Mass Communication Quarterly, 8I(3), pp. 622-642.

Jones, D. A. (2004) 'Why Americans Don't Trust the Media', Harvard International Journal of Press/Politics, (2), pp. 60-75.

Kenski, K. and Jamieson, K. H. (20I I) 'Presidential and Vice Presidential Debates in 2008: A Profile of Audience Composition', American Behavioral Scientist, 55(3), pp. 307-324.

Kenski, K. and Stroud, N. J. (2005) 'Who Watches Presidential Debates? A Comparative Analysis of Presidential Debate Viewing in 2000 and 2004', American Behavioral Scientist, 49(2), pp. 213-228.

Konstantinov, P. S. (2016) Referendum 2016: Za mazhoritarnite izbori i imitatsiata na demokratsia [Referendum 2016: On majoritarian elections and imitation of democracy], Dnevnik.

Kostadinova, P. and Popova, M. (2014) 'The 2013 parliamentary elections in Bulgaria', Electoral Studies, 34, pp. 365-368. doi: 10.1016/j.electstud.2013.09.013.

Kostadinova, P. and Popova, M. (2015) 'The 2014 parliamentary elections in Bulgaria', Electoral Studies, 38, pp. II4-II8. doi: 10.1016/j.electstud.2015.01.009.

Kourtova, P. (2012) Slavi Trifonov and the Commodification of Nationalism: Popular Culture, Popular Music, and the Politics of Identity in Postsocialist Bulgaria, 1990-2005. Florida State University.

LeDuc, L. (2002) 'Referendums and elections: How do campaigns differ?', in Farrell, D. M. and Schmitt-Beck, R. (eds) Do Political Campaigns Matter? Campaign effects in elections and referendums. London and New York: Routledge, pp. I45-162.

Lupia, A. and Johnston, R. (200I) 'Are Voters to Blame? Voter Competence and Elite Maneuvers in Referendums', in Mendelsohn, M. and Parkin, A. (eds) Referendum Democracy: Citizens, Elites and Deliberation in Referendum Campaigns. Basingstoke: Palgrave Macmillan, pp. $191-210$.

Maier, J. and Faas, T. (20II) “'Miniature Campaigns” in Comparison: The German Televised Debates, 2002-09', German Politics, (I), Pp. 75-91.

Mediapool.bg (2016) Prezidentat nasrochi referenduma na Slavi za 6 noemvri [The President 
scheduled Slavi's referendum for 6 November].

Mendelsohn, M. and Parkin, A. (eds) (200I) Referendum Democracy Citizens, Elites and Deliberation in Referendum Campaigns. Basingstoke: Palgrave Macmillan.

Minchev, O. (2016) Kogato vi predlozhat byuletina za referenduma, kazhete 'Ne, blagodarya' [When you get offered a ballot for the referendum, just say 'No, thank you'].

Nielsen Admosphere Bulgaria (2016) Nielsen Admosphere Bulgaria Newsletter 7/20I8.

Norris, P. and Curtice, J. (2008) 'Getting the Message Out: A Two-Step Model of the Role of the Internet in Campaign Communication Flows During the 2005 British General Election', Journal of Information Technology \& Politics, 4(4), pp. 3-I3.

O'Leary, C. and Hesketh, T. (1988) 'The Irish abortion and divorce referendum campaigns', Irish Political Studies, 3(I), pp. 43-62.

Ridout, T. N. and Smith, G. R. (2008) 'Free Advertising: How the Media Amplify Campaign Messages', Political Research Quarterly, 6I (4), pp. 598-608.

Saglie, J. and Vabo, S. I. (2009) 'Size and e-Democracy: Online Participation in Norwegian Local Politics', Scandinavian Political Studies, 32(4), pp. 382-40I.

Schuck, A. R. T. and de Vreese, C. H. (2009) 'Reversed Mobilization in Referendum Campaigns: How Positive News Framing Can Mobilize the Skeptics', The International Journal of Press/Politics, I4(I), pp. 40-66.

Silagadze, N. and Gherghina, S. (2018) 'When who and how matter: explaining the success of referendums in Europe', Comparative European Politics, I6(5), pp. 905-922.

Simov, A. (2016) Zvezdata na kyucheka Slavi shte bade naritan na izbori. Balatsite shte leyat karvavi salzi, ako se podvedat po Dalgia [The belly dance star Slavi will be badly beaten on elections. The suckers will cry blood tear if they fall for the Long One], Pik.bg.

Slavi's Show (2015a) Initsiativen komitet ot shouto shte intsiira podpiska za referendum [A civic initiative committee from the Show will initiate a signature collection for the referendum].

Slavi's Show (20I5b) Prez septemvri startira sabiraneto na podpisi za referendum [The gathering of signatures for a referendum starts in September].

Slavi's Show (2015c) Referendum s 6 vaprosa [Referendum with 6 questions].

Steenbergen, M. R., Edwards, E. E. and de Vries, C. E. (2007) 'Who's Cueing Whom? MassElite Linkages and the Future of European Integration', European Union Politics, 8(I), PP. I3-35.

Stoyanov, D. (2015) 'The 2014 Electoral Code Initiative in Bulgaria', East European Quarterly, 43(2-3), pp. 217-224.

Stoychev, S. P. (2017) 'The 2016 Referendum in Bulgaria', East European Quarterly, 45(3-4), Pp. 187-194.

Taggart, P. (2006) 'Keynote article: Questions of Europe: the domestic politics of the 2005 French and Dutch referendums and their challenge for the study of European integration', Journal of Common Market Studies, 44(s I), Pp. 7-25.

Theocharis, Y. and van Deth, J. W. (2017) Political Participation in a Changing World. Conceptual and Empirical Challenges in the Study of Citizen Engagement. New York: Routledge.

Tsfati, Y. and Cappella, J. N. (2003) 'Do People Watch what they Do Not Trust?', Communication Research, 30(5), pp. 504-529.

de Vreese, C. H. (ed.) (2007) The Dynamics of Referendum Campaigns: An International Perspective. Basingstoke: Palgrave Macmillan.

de Vreese, C. H. and Semetko, H. A. (2004) Political Campaigning in Referendums. Framing the referendum issue. London and New York: Routledge.

Wettstein, M. (2012) 'Frame Adoption in Referendum Campaigns: The Effect of News Coverage on the Public Salience of Issue Interpretations', American Behavioral Scientist, 56(3), pp. 318-333. 
